\title{
On the Syntactic Status of Edo Ideophones
}

\author{
Edosa James Edionhon * \\ (University of Benin, Nigeria)
}

\begin{abstract}
Ideophones are a particular lexical class of expressive words depicting perceptual events or states, and are said to be a universal or near-universal feature of language (Dingemanse, 2012:655; Kilian-Hatz, 2001:163). This paper presents an overview of Edo ideophones to characterize them in terms of their occurrence in grammatical syntactic frames. It investigates what sets them apart within word classes in Edo and how they differ from their non-ideophonic counterparts in sentential constructions. The Basic Linguistic Theory was adopted as the method for data analysis. This was done to show how ideophones manifest syntactically in the language. Ideophones appear in copular frames with some verbs in the language, especially the verb 'to be'. This paper concludes that Edo ideophones do not occur pre-nominally in the language.
\end{abstract}

Keywords: ideophones, modification, question, E.do, nouns, verbs

\section{Introduction}

This paper examines the syntactic status of Edo ideophones. In the syntactic analysis, our concern will be on the syntactic environments, that is, whether the ideophones can occur attributively and/or predicatively. It also seeks to examine if the ideophone acts as a modifier in a sentence and if yes, how do ideophones in Edo modify nouns and verbs that they collocate with; and if ideophones could also be used in question formation of yes-no or wh-questions.

The Edo language belongs to the Kwa sub-group of the Niger-Congo phylum in Greenberg's (1963) classification of African languages and is found in the North Central Edoid (NCE) branch of the genetically related languages and dialects referred to as the 'Ẹdoid group of Languages' in Elugbe's (1989) classification. The language is spoken in Edo State in the southern part of Nigeria.

Over the years, ideophones have persisted in presenting complex challenges for syntactic interpretation (Welmers, 1973). Doke (1935:118) defined ideophones as the "vivid representation of an idea in sound; a word, often onomatopoeic, which describes a

\footnotetext{
* Edosa James Edionhon: Lecturer II, Deptartment of Linguistics Studies, Faculty of Arts, University of Benin, Benin City, Nigeria. E-mail: james.edionhon@uniben.edu.
} 


\section{On the Syntactic Status of Edo Ideophones}

predicate, qualificative or adverb in respect of manner, colour, smell, action state or intensity". They can be found in many languages of the world. Despite that, they have long been relegated to the fringes of language description. This is partly because they generally do not form a significant part of the lexicon of the highly-studied Indo-European languages, and that there is no precise definition of the term 'ideophone' that can be applied to all languages, since the characteristics of these words, in terms of form, syntax, semantics, and use, vary from one language to another (Smoll, 2014). According to Childs (1994), ideophones frequently occur in a syntactically rigid expression with a "dummy" verb meaning 'do', 'say', 'speak', or 'sit', and in the discourse, they often occur grammatically unconnected with sentences. Although both features underscore the unassimilated syntactic nature of ideophones, it is the former, the ideophone collocation with verbs meaning 'do' or 'say' in particular, that attracts our attention.

\section{Literature review}

The term 'ideophone' is generally used when referring to African languages, whereas in Asian languages, they are mostly called 'expressives' (Diffloth, 1976). Ideophones are words, that is, conventionalized minimal free forms with specifiable meanings (Crowther, 1852). Although their meanings are notoriously difficult to describe, they have been successfully studied using a variety of methods (Samarin, 1967, 1970; Difforth, 1972). Ideophones depict 'sensory imagery'. Sensory imagery is perceptual knowledge that derives from the sensory perception of the environment and the body (Paivio, 1986).

Subcategorization of languages based on the derivation mechanisms applicable to ideophones might involve particular types of words that can be derived from ideophones and those that can be used to derive ideophones. For example, Childs (1994a:186) noted the cross-linguistically frequent relationship between verbs and ideophones (at least in African languages), but he avoided making claims about the directionality of the derivation, as this can be difficult to determine. There does appear to be a tendency for languages to derive ideophones from verb roots and nominal forms from ideophones (Bartens, 2000:141). However, McGregor (2001) made a strong case for attributing the origins of a compound verb construction in Northern Australian languages to ideophonic sources (Smoll, 2014).

Smoll (2014) stated that both the syntactic form and the function of ideophones generally follow those of the class of words to which they belong (often with a few idiosyncrasies peculiar to ideophones). In languages where ideophones are less integrated into the grammar, on the other hand (i.e. ideophones form a class of their own or a subcategory of one class), ideophones differ syntactically in terms of their level of 'aloofness', or independence in a clause, their collocational restrictions, and the sentence 
types in which they occur. Taking into account both these types of ideophones, a broad four-way distinction can be made (based on works by Bartens, 2000; Creissels, 2001 and cited in Smoll, 2014):

Type 1: Sound symbolic nouns, adjectives, adverbs, etc. These follow the syntactic patterns of the class of words to which they belong, with perhaps a few syntactic idiosyncrasies particular to them. It might be more useful to label these as 'sound symbolic nouns', 'sound symbolic adjectives' and so on, rather than 'ideophones', as they are generally fully incorporated into the grammar, and are only considered to be ideophones because of their particular phonological and morphological shapes (extended phoneme inventory and reduplication) as well as their sound symbolic nature. Many words in English, such as the sound symbolic nouns bling, referring to shiny and expensive jewelry, and flim-flam, referring to a confidence trick, can be categorized as this type.

Type 2: Ideophones that modify verbs/predicates, nouns, and/or adjectives: This type of ideophones are presented in type $2 \mathrm{a}, 2 \mathrm{~b}$, and $2 \mathrm{c}$ below:

a. Ideophones that modify verbs

The meanings of these ideophones are often very general, but in combination with a particular verb, either their meaning of the ideophone or that of the verb becomes more specific, or the ideophone serves to intensify the main verb. In the latter case, the ideophone often has a meaning very close to or is in a quasi-synonymous relationship with the main verb. In ChiTumbuka, for example, ideophones can only co-occur with verbs to which they are directly related, in that one is derived from the other (Mphande, 1989:34 \& 36):

(1) Mwana wakozga a nyina kozge.

'The child resembles the mother exactly/completely.'

(2) Delele la lelenduka lelendu.

'The okra has become very, very sticky.'

In some languages, it is also possible to leave the verb unexpressed in these types of constructions, resulting in increased vividness and speed in communication.

b. Ideophones that modify nouns

Degaare

\begin{tabular}{|c|c|c|c|c|}
\hline (3) $\grave{a}$ & dうう zú & bònggòlòng & ná & wàc \\
\hline DEF & man head & IDEO (unwieldy-like/big) & DEM & come \\
\hline
\end{tabular}

'The man with the big/unwieldy head has come.' ～(cf: Bodomo, 2006:206)

c. Ideophones that modify adjectives

Temne
(4) $\grave{U}$-wá $\quad \grave{u}$-lòs pít
konj̀ dèr.
CL-child CL-bad IDEO(very) 3SG come 


\title{
On the Syntactic Status of Edo Ideophones
}

\author{
'A very old man arrived.' \\ (cf: Kanu, 2008:128)
}

Type 3: Ideophones that collocate with an auxiliary verb often meaning 'say', 'do', or 'be' although sometimes other verbs may be used, such as 'go', 'fall', or 'beat' as in Kanuri (Western Saharan - Hutchison, 1989:4, cited in Childs, 1994a:187), or an indefinite verb with the meaning 'has the qualities of' (Emenanjo, 1978, cited in Childs, 1994a:187). The restriction is semantically rather than syntactically determined. Structures of this type are considered to be quotative constructions in which the meaning and the subcategorization properties are determined entirely by the particular ideophone (Creissels, 2001:78). In these types of verbal compound constructions, the lexical meaning and the argument structure of the compound are determined by the ideophone, whereas the grammatical elements of a verb form such as subject/object markers, tense, aspect, and mood (TAM) are carried by the auxiliary.

Type 4: Ideophones that are the least grammatically integrated of ideophones and display a high degree of 'syntactic aloofness' - they may even be syntactically independent. As Kilian-Hatz (2001:157) puts it, they often 'have sentence-like character and denote inherently not only a state or an action but also the cause and other participants (e.g. patient, instrument, etc.) of the event'. These correspond to Dwyer \& Moshi's (2003) primary ideophones. Often, they can fully replace argument-predicate structures. In Mon-Khmer languages, for example, ideophones generally function as independent clauses. They are "uttered in isolation as minor sentences" (Svantesson, 1983:79). Similarly, in Yir-Yoront, ideophones display a large amount of aloofness. They can occur either immediately before the verb (e.g. Ngoyo Tor piw ungh. 'Tor! I hit him.', Ngoyo Kat kil ungh.. 'Kat! I speared it.'), intonation- (usually clause-) finally and separated by a falling intonation contour (e.g. Piw 'y ungh, Tor! 'I hit him, Tor!', Kil 'y ungh, Kat! 'I speared it, Kat!'), or in sentences where the verb is absent but understood (e.g. Ngoyo Kat! 'I [speared it], Kat!') (Alpher, 1994:168).

It must be noted that the borders of these categories are quite fuzzy. It is not always clear to which category a given ideophone belongs, and some ideophones might fit into more than one category depending upon the context in which they are used. Nevertheless, the classification outlined above proposes a scale ranging from ideophones highly assimilated into the grammar of the language to those least assimilated. If we consider Type 1 words to simply be sound symbolic words of one or another grammatical category, a language's ideophones can be of Type 2, 3, or 4, or more commonly, a language will have a mix of two or more of these types (Smoll, 2014).

Some further generalizations that can be made about ideophones involve the types of clauses in which they occur. For example, ideophones tend to occur in affirmative declarative clauses which are the main sentence type of narratives (Bartens, 2000:35). This 
does not apply to ideophones in all languages, however, as they can appear in sentences containing the present indicative in Cilub'a (Kabuta, 2001:146), future tense in Southern Sotho (Kunene, 1978:12), and imperative sentences in Yir-Yoront, Uw-Oykangand (Paman) (Alpher, 2001:11), and Katuena. Katuena ideophones also occur in interrogatives. That ideophones tend not to occur in negative sentences is not surprising given the fact that the function of ideophones is to simulate or depict an event or sensation, not its absence (Kilian-Hatz, 2001:158). In some rare cases, however, they can occur in negative sentences, as in Baka, where constructions of this sort are used for rhetorical effect.

\section{The syntax of Edo ideophones}

The syntax of ideophones involves the evaluation of the structural distributions of certain ideophones in a clause alongside other elements like nouns and verbs. It is to be noted that most ideophones in the Edo language are adverbials and adjectives which exist to modify the verbal and nominal elements in a clause respectively. This section will examine the structure of ideophones in sentential constructions: the syntactic environment to which the ideophones occur in the language; the role of the ideophones in sentence modification; how are ideophones in the language used in question formation, whether they form a complete or grammatical form of their own, that is, and whether they have a sentence-like character or not among others.

\subsection{The syntactic environment of Édo ideophones}

In a sentence, there is a subject part and also a predicate part. Depending on the language, ideophones can occur either as subjects or as predicates. Some ideophones occur attributively or predicatively. Attributive and predicative in this sense refer to the position of an ideophone in a sentence. An ideophone is used attributively when it comes before a noun and predicatively when it comes after the verb in a sentence. The syntax and semantics of ideophones in Edo are linked in that the position of the ideophone in the clause determines its semantic function. Let us consider the examples below:

(5) a. Èdèdé ghá gùọ highàhighà
Old woman tremble (Pres.) IDEO
'The old woman is trembling nervously.'
b. İnyá nè Èfó!sà dẹlé yé lẹúlẹú
Yam that Efosa buy (Pres.) be IDEO
'The yams Efosa bought are very large.'
c. Ègbé bọlọzọ ẹré Amẹ!zẹ mwẹe
Body IDEO Foc. Ameze own
'Ameze's body is fleshy. / Ameze is healthy-looking.'




\section{On the Syntactic Status of Edo Ideophones}

$\begin{array}{cllll}\text { d. Ékítà } & \text { né mitànmitàn } & \text { ẹré } & \text { Òsàsú dẹrè } \\ \text { Dog } & \text { that } & \text { IDEO } & \text { Foc. } & \text { Osasu buy (Pst.) }\end{array}$

'The dog that Osasu bought is very weak / lazy.'

e. Ùnwọmwè nè òghọghọ lérè yé lòghòlòghò

Soup that Oghogho cook be IDEO

'The soup that Oghogho cooked is watery.'

In the examples above, it was observed that Edo ideophones occur either at the clause-medial or clause-final position. Examples $(5 \mathrm{a}, \mathrm{b}, \mathrm{e})$ attest that ideophones in the language function predicatively while examples $(5 \mathrm{c}, \mathrm{d})$ attest that the ideophones also function attributively. The attributive nature of ideophones in the language shows that they occur after the subject and it qualifies either directly after the noun or after the relativizer $n \dot{e}$.

\subsection{Ideophones as modifiers}

Stageberg (1981) defined a modifier as a subordinate element in an endocentric structure: "a word or word group that affects the meaning of a headword in that it describes, limits, intensifies and/or adds to the meaning of the head". Miller (2002) opined that "if we think of a language as a way of conveying information ... we can consider the head as conveying a central piece of information and the modifiers as conveying extra information".

Syntactically speaking, Edo ideophones can be classified into nominal ideophone modifiers and verbal ideophone modifiers as represented below:

\subsubsection{Ideophones that modify nouns}

These are ideophones that modify and specify the qualities of nouns (especially subject NPs) as used in discourse. These ideophones are adjectival and are used to reinforce the qualities, features, and number of an event performer in a clause.

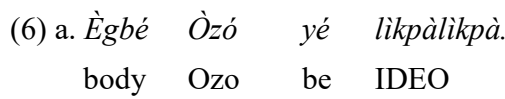

'Ozo's body/skin is very rough/not smooth.'

b. Nénè òwá yé mòsèmòsè.

the house be IDEO

'The house is very beautiful.'

$$
\begin{aligned}
& \text { c. Ékità nà yé khòrhionkhòrhiòn } \\
& \operatorname{dog} \text { this be IDEO } \\
& \text { 'This dog is very ugly.' } \\
& \text { d. Èvbàré mwé yé zúnézúné. } \\
& \text { food my be IDEO } \\
& \text { 'My food is very small.' }
\end{aligned}
$$

The adjectives in (6a-d) above are used to intensify the entity being modified. These 
adjectives are always preceded by the verb, yè 'be' in a clause. These adjectives are the reduplicants of the base adjectives: likpà, mòsè, khòrhion and zùnè in the clause. They occur in clause-final positions and the verb in this type of sentences is yè 'be' that subcategorizes only for the subject nominals. The examples given above are for the subject nominals which occur in clause-initial position.

Object nominal can also be modified by these ideophones as the following examples show:

$$
\begin{aligned}
& \text { (7) a. Òmó né kpùvbièkpùvbịe ẹrè Érháuyì biérè. } \\
& \text { Child Rel. IDEO. Foc. Erhauyi give birth + Pst. (Rv) } \\
& \text { b. Ėwé né khụonmwikhùonmwì ẹrè Òsàyi dérè } \\
& \text { Goat Rel. IDEO Foc. Òsàyí buy + Pst. (Rv) } \\
& \text { c. Ùwònmwèe né ó yé lóghólóghó ẹrè Èkì lérè } \\
& \text { Soup Rel. Pron. be IDEO Foc. Ẹkì cook + Pst. (Rv) } \\
& \text { d. Egéré nè ò sié dúdúdú érè iyé mwè dérè } \\
& \text { Pot Rel. Pron. be IDEO Foc. mother my buy + Pst. (Rv) }
\end{aligned}
$$

'The pot that is very black was bought by my mother.'

$$
\begin{array}{cllllll}
\text { e. Ọkhókhò } & n e ̀ ~ & o & \text { rù dùedùe } & \text { ẹrè .Elémá dérè } \\
\text { Fowl } & \text { Rel. } & \text { Pron. } & \text { do } & \text { IDEO } & \text { Foc. Élémá buy + Pst. (Rv) }
\end{array}
$$

'The fowl that is behaving sluggishly was bought by.Élemá.'

The ideophones here are used to qualify the object elements in the clauses represented above which have been used in focus position. The position of these ideophones remains the same as that in the earlier examples provided which is clause-medial position immediately after the verb.

\subsubsection{Ideophones that modify verbs}

These are adverbials used to modify the verbs in a discourse whereby the nature of the activity embarked on by an entity is emphasized. Verbal ideophones in Edo occur in the clause-final position immediately after the verb with the only difference being the entity qualified by the ideophone.

$$
\begin{aligned}
& \text { (8) a. Òsàwé khìàn bìzùbìù. } \\
& \text { Osawe walk (Pres.) IDEO } \\
& \text { 'Osawe is walking haphazardly.' } \\
& \text { b. Ùnúágḅon gùán gbàigbàì. } \\
& \text { Unuagbon talk (Pres.) IDEO } \\
& \text { 'Unuagbon talks audibly.' }
\end{aligned}
$$




\section{On the Syntactic Status of Edo Ideophones}

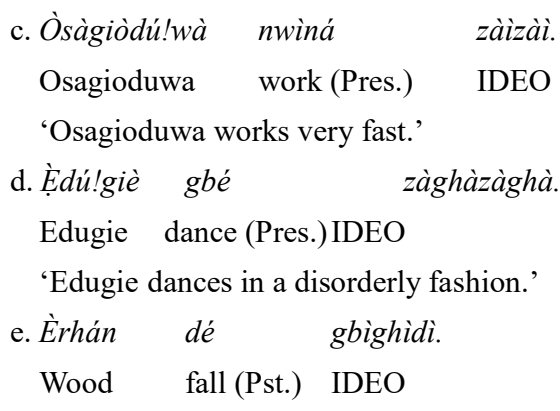

'The wood fell with a loud noise.'

The ideophones used in the clauses above are verbal modifiers as they qualify the action of the subject nominal. The verbs are in most cases action verbs and intransitive as they practically take no object nominal.

There are a few instances of inter-clausal ideophones (that is, ideophones that occur before the verb and not at the clause-final position based on the examples above). These ideophones are always preceded by the relativizer (né) instead of the normal prepositional element (yé), which is portrayed by the data below:

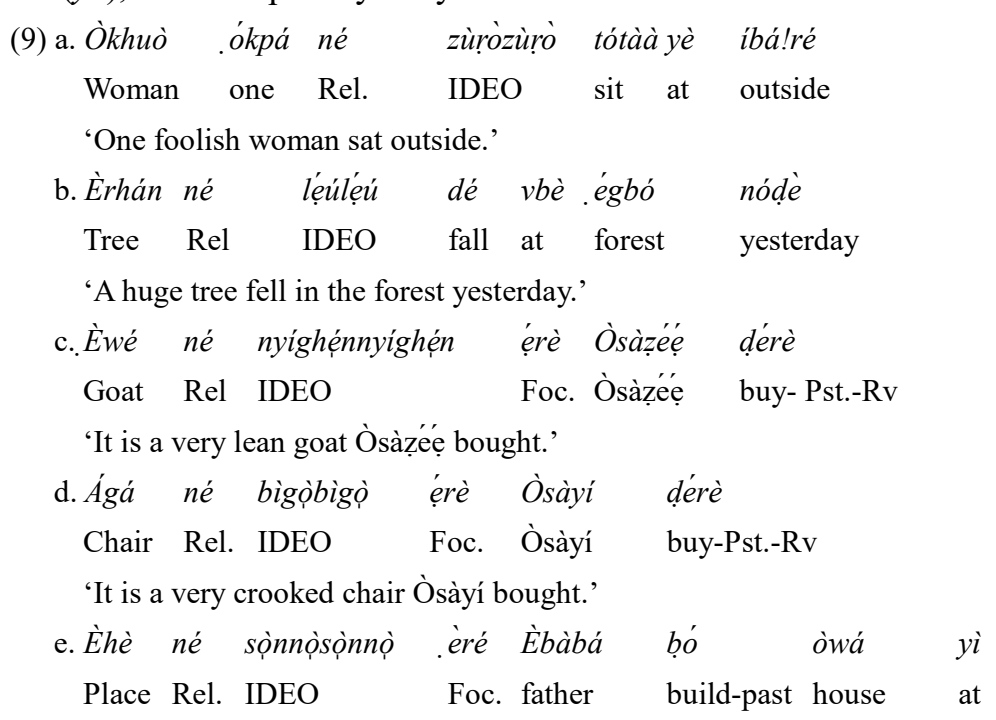

'It is in a flat place that father built his house.'

Ideophones as observed in the examples above are used in clause-medial positions, signaling the fact that these elements are not restricted only to the clause-final position in discourse. Two things are noticeable about these ideophones. The first is the use of the relative marker nè (relative pronoun) and the second is the use of the focus marker ere (focalizing copula) implying the movement of an object element from the clause-final position to the clause-initial position. 


\subsection{Ideophones in questions}

Other than being used in declarative sentences and in focus constructions, ideophones can also be used in questions. According to Omoigui (1987:5), 'questions could be regarded as a generic term for several constructions that require information from an addressee; differ in form and function and can be divided into different classes according to the type of answers they elicit'. In Edo question formation, ideophones can be used in yes/no as well as wh-questions. Consider the examples below:

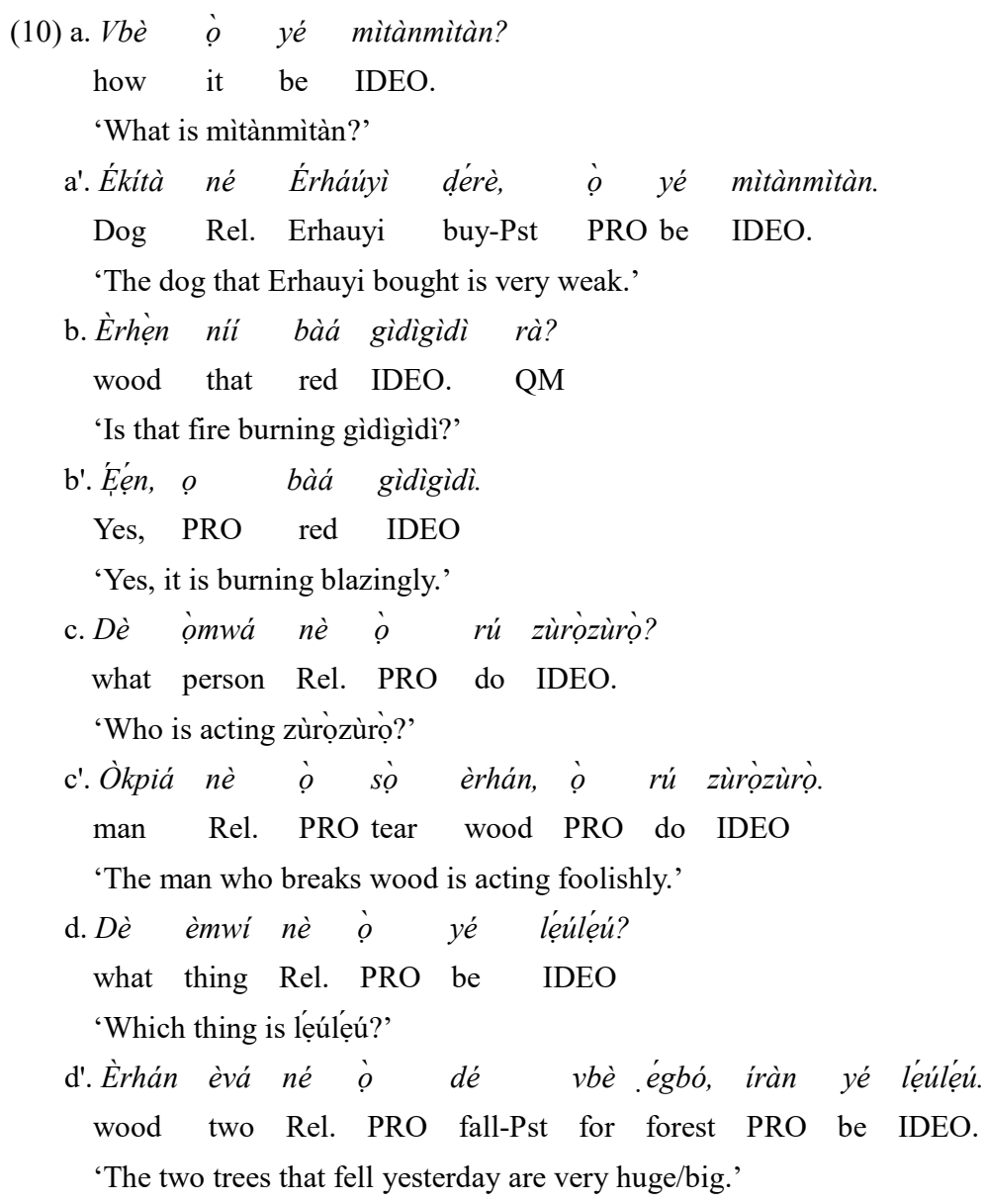

Ideophones in the examples above, can be used in wh-question as well as yes-no questions in the language. In this type of question, the focus is not on the argument but the ideophone because it is the attribute of the argument that the speaker is inquiring about. The descriptive nature of the ideophone makes it the focus of the question. The response will make the information more explicit based on what is described.

There are also questions without ideophones in them that may require a response with 


\section{On the Syntactic Status of Edo Ideophones}

ideophones. Some of these questions end with the rẹ particle. Let us consider the following examples:

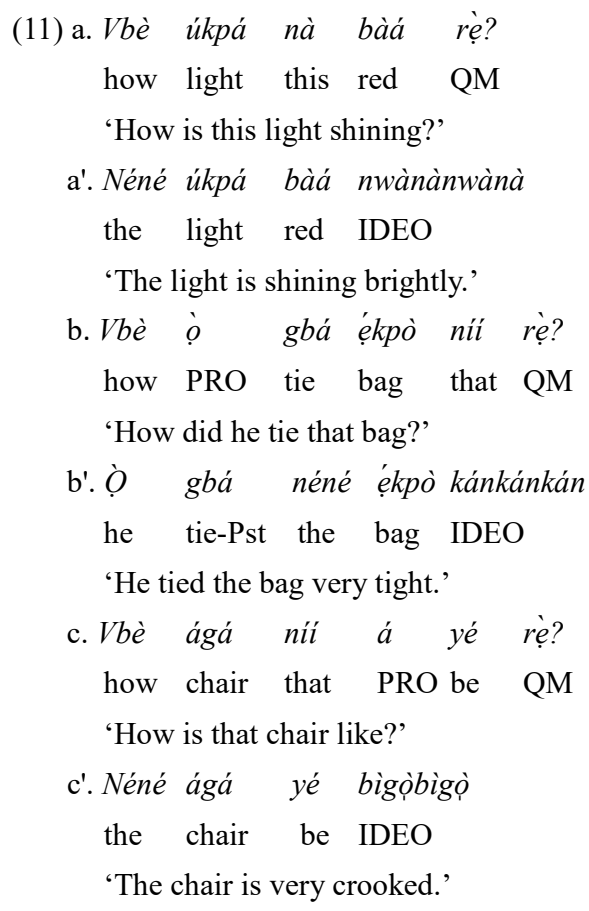

In the examples above, the speaker wants to know the status of the arguments (úkpá, ékpò and ágá) in the interrogative sentence. The response to the question(s) will introduce the ideophone to give extra information about the argument. The speaker in example (11a) wants to know the manner in which the light is shining or the brightness of the light. The response introduces an ideophone nwànànwànà to give extra information about the brightness of the light. The same applies to (11b) and (11c) respectively.

\section{Conclusion}

The syntactic analysis examined the syntactic environment in which ideophones occur to determine if they occur attributively and/or predicatively. Our study revealed that Edo ideophones occur both at attributive and predicative positions. At the attributive position, the ideophone is preceded by a subject NP and the relativizer $n e ̀$. At the predicative position, the ideophones occur at the sentence-final position. Ideophones were found to be focused in the language. This is because the emphasis of the sentence is on the ideophone and it describes the arguments by way of giving more information about the arguments. Ideophones could also be used in question formation of yes-no or wh-questions.

What was also examined in this paper is the modification of nouns and verbs with 
ideophones, where the ideophone acts as a modifier in a sentence. It was observed that Edo ideophones act as nominal and verbal modifiers. As a nominal modifier, the ideophone, depending on the sentential construction, could modify the subject and the object of a sentence. In modifying the subject, the ideophone precedes the copula verb ye and subcategorizes for a subject nominal. The ideophones are used to qualify objects of a sentence when the object is the recipient of the ideophone action. As verbal modifiers, they qualify the action(s) of the subject nominal and practically do not take object nominals. The study also observed that E.do ideophones do not occur at sentence-initial positions (as subjects) but at sentence-medial and sentence-final positions.

$\begin{array}{llll}\text { Abbreviations } & & \\ \text { CL } & \text { Classifier } & \text { PRO } & \text { Pronoun } \\ \text { DEF } & \text { Definite Article } & \text { Pron. } & \text { Pronoun } \\ \text { DEM } & \text { Demonstrative } & \text { Pst. } & \text { Past Tense } \\ \text { Foc. } & \text { Focus Marker } & \text { QM } & \text { Question Marker } \\ \text { IDEO } & \text { Ideophone(s) } & \text { Rel. } & \text { Relativizer } \\ \text { Pres. } & \text { Present Tense } & \text { Rv } & \text { Rv-suffix }\end{array}$

\section{References}

Alpher, B. 2001. Ideophones in Interaction with Intonation and the Expression of New Information in Some Indigenous Languages of Australia [A]. In F. K. E. Voeltz \& C. Kilian-Hatz (eds.), Ideophones (Typological Studies in Language 44) [C]. Amsterdam \& Philadelphia: John Benjamins, 9-24.

Bartens, A. 2000. Ideophones and Sound Symbolism in Atlantic Creoles [M]. Saarijärvi: Gummerus Printing.

Bodomo, A. 2006. The Structure of Ideophones in African and Asian Languages: The case of Dagaare and Cantonese [A]. In J. Mugane, J. Hutchison \& D. Worman (eds.). Selected Proceedings of the 35th Annual Conference on African Linguistics [C]. Somerville, MA: Cascadilla Proceedings Project, 203-213.

Childs, G. T. 1994. African Ideophones [A]. In L. Hinton, J. Nichols \& J. J. Ohala (eds.). Sound Symbolism [C]. Cambridge: Cambridge University Press.

Creissels, D. 2001. Setswana Ideophones as Uninflected Predicative Lexemes [A]. In F. K. E. Voeltz \& C. Kilian-Hatz (eds.), Ideophones (Typological Studies in Language 44) [C]. Amsterdam \& Philadelphia: John Benjamins, 75-85.

Crowther, S. A. 1852. A Grammar of the Yoruba Language [M]. London: Seeleys.

Diffloth, G. 1972. Notes on Expressive Meaning [J]. Chicago Linguistic Society, 8:440-447.

Diffloth, G. 1976. Expressives in Semai [J]. Oceanic Linguistics Special Publications, (13):249-264.

Dingemanse, M. 2012. Advances in the Cross-Linguistic Study of Ideophones [J]. Language and Linguistics Compass, 6(10):654-672.

Doke, C. M. 1935. Bantu Linguistic Terminology [M]. London, UK: Longman, Green \& Co.

Dwyer, D. \& L. Moshi. 2003. Primary and Grammaticalized Ideophones [A]. In J. Mugane (ed.). The Linguistic Typology and Representation of African Languages [C]. Trenton: Africa World Press, 173-185.

Elugbe, B. O. 1989. Comparative Edoid: Phonology and lexicon (Delta Series. No 6.) [M]. Port Harcourt: University of Port Harcourt Press.

Emenanjo, E. 1978. Elements of Modern Igbo Grammar [M]. Ibadan: Oxford University Press.

Greenberg, J. H. 1963. The Languages of Africa [M]. Bloomington: Indiana University Press.

Hockett, C. F. 1958. A Course in Modern Linguistics [M]. New York: Macmillian.

Hutchison, J. 1989. The Kanuri Ideophone [A]. In The Ideophone Colloquium, 20th Conference on African Linguistics [C]. Urbana-Champaign: University of Illinois.

Kabuta, N. S. 2001. Ideophones in Cilubà [A]. In F. K. Voeltz \& C. Hatz-Kilian (eds.). Ideophones 


\section{On the Syntactic Status of Edo Ideophones}

(Typological Studies in Language 44) [C]. Amsterdam: John Benjamins Publishing Company, 139-154. Kanu, S. 2008. Ideophones in Temne [A]. Kansas Working Papers in Linguistics [C]. Lawrence: University of Kansas, 30:120-134.

Kilian-Hatz, C. 2001. Universality and Diversity: Ideophones from Baka and Kxoe [A]. In F. K. Voeltz \& C. Hatz-Kilian (eds.). Ideophones (Typological Studies in Language 44) [C]. Amsterdam: John Benjamins Publishing Company, 155-164.

Kunene, D. P. 1978. The Ideophone in Southern Sotho [M]. Berlin: Dietrich Reimer

McGregor, W. 2001. Ideophones as the Source of Verbs in Northern Australian languages [A]. In Voeltz/ Kilian-Hatz (ed.). Ideophones (Typological Studies in Language 44) [C]. Amsterdam \& Philadelphia: John Benjamins Publishing Company, 205-221.

Miller, J. 2002. An Introduction of English Syntax [M]. Edinburgh: Edinburgh University Press.

Mphande, L. 1989. A Phonological Analysis of the Ideophone in ChiTumbuka [D]. Ph.D. Dissertation. Austin: University of Texas.

Paivio, A. 1986. Mental Representations: A dual coding approach [M]. New York: Oxford University Press. Omọigui, E. M. 1987. Yes-No and Wh Questions in Edo: A transformational generative approach [D]. MA Thesis. Ibadan: University of Ibadan.

Samarin, W. J. 1967a. Determining the Meaning of Ideophones [J]. Journal of West African Languages, $4(2): 35-41$.

_. 1970a. Field Procedures in Ideophone Research [J]. Journal of African Languages, 9(1):27-30.

1970b. Inventory and Choice in Expressive Language [J]. Word, 26(2):153-169.

Smoll, L. I. 2014. Me:ruгu, фoku, and tfitowis: An analysis of ideophones in Katuena (Tunayana) [D]. MA Thesis. Leiden: Leiden University Centre for Linguistics.

Stageberg, N. C. 1981. An Introductory English Grammar (4th ed.) [M]. New York: Holt, Rinehart \& Winston Inc.

Svantesson, J. 1983. Kammu Phonology and Morphology (Travaux de L'Institut de Linguistique de Lund, 18) [M]. Lund: Lund University.

Welmers, W. E. 1973. African Language Structures [M]. Berkeley: University of California Press. 